\title{
References:
}

1. Bouquet, E. (2015). Muzeini predmety iz fondovoi kolektsii NIEZ «Pereiaslav», shcho pokhodiat $\mathrm{z}$ sela Hruzkoho Makarivskoho raionu Kyivskoi oblasti [Museum items from the Pereyaslav National Research Institute stock collection, originating from the village of the Georgian Makariv district of Kyiv region]. Pereiaslavik: Scientific notes of the National Historical and Ethnographic Reserve «Pereyaslav»: Collection of scientific articles, vol. 9 (11), p. 46.

2. Godlina, L., \& Dunayna, I. (2014). Kultovi atrybuty u zbirtsi Natsionalnoho istorykoetnohrafichnoho zapovidnyka «Pereiaslav» [Cult attributes in the collection of «Pereyaslav» National Historical and Ethnographic Reserve]. Pereiaslavik: Scientific Notes of «Pereiaslav» National Historical and Ethnographic Reserve: Coll. Sciences. Articles, vol. 7 (9), pp. 79-80.

3. Materialy fondovoi inventarnoi knyhy Natsionalnoho istoryko-etnohrafichnoho zapovidnyka «Pereiaslav». Inventarna hrupa «K» (Keramika»), «NDF» («Naukovo-dopomizhnyi fond»), «PKhIM» («Pereiaslav-Khmelnytskyi istorychnyi muzei»). [Materials of the stock inventory book of «Pereiaslav» National Historical and Ethnographic Reserve. Inventory group «C» (Ceramics), «SSF» (Scientific Support Fund), «PKHM» (Pereyaslav-Khmelnitsky History Museum)].

\section{WOMEN'S EARRING COLLECTION IN NATIONAL HISTORICAL-ETHNOGRAPHIC RESERVE «PEREIASLAV»}

\section{Iryna Dunaina ${ }^{1}$}

DOI: https://doi.org/10.30525/978-9934-588-11-2_24

The Ukrainian women's folk ornaments collection in the National Historical and Ethnographic Reserve (hereinafter referred to as NIEZ «Pereiaslav») began to form in 1959.It represents the neck, chest, ear jewelry which refer to the lands of the Middle Dnieper region, in particular Pereyaslav, Poltava, Kyiv, Left and Right (partly) Cherkasy and Chernihiv (partly) regions. The collection contains about 311 pieces of museum artifacts of late XVIII - mid. XX century, which are recorded and stored in the stock groups of «Numismatic», «Fabric».

These are :

- necklace - 147 pieces;

- chain - 7 pieces;

- dukach (lychman), bow - 102 pieces;

- medallion - 1 piece;

- Earring - 50 pieces;

- brooch -4 pieces.

Thanks to museums, which meticulously were engaged in scientific and practical work on the identification, attribution, preservation and introduction to the scientific circulation of the historical and cultural heritage of the people, these artifacts of folk culture have taken a prominent place in museum collections. The museum collection was created thanks to the ethnographic expeditions of the reserve, which worked in

\footnotetext{
${ }^{1}$ National Historical and Ethnography Reserve «Pereiaslav», Ukraine 
these regions in the 70's - 90's of the XX century. A considerable amount of material was received from the residents of the city and its district as individual finds.

Jewelry has always been a complementary element in folk dress, its compositional and decorative finish, without which the unity of the artistic ensemble was broken. They were given aesthetic, magical, symbolic functions. Comparing archaeological sites with museum specimens of the 17th - early 20th centuries, it is easy to track the genetic connection of the jewelry from ancient times until the 20th century. Each region of Ukraine had its own traditional jewelry identity. Keeping in common, the populations of individual counties and even villages created their own original sets. Thanks to the goldsmiths who invested all their skills and talent in making a variety of extraordinary women's jewelry. They continued to follow ancient traditions in a slightly different interpretation. Thus, among the variety of women's folk ornaments, a prominent place is occupied by women's ear ornaments, which the museum collection has 50 pieces of preservation.

Like the necklace, earrings are one of the most favorite Ukrainian women's jewelry. They are represented by Pereyaslav, Poltava, Cherkasy region. In Pereyaslav Region they were varied both in form and composition. There are 25 artifacts in the collection, 3 of which are parts from units. They are characterized by a great variety of forms, constructive structure, ornamentation, artistic principle. One of the most famous earrings that had a complex design were «Pereiaslav» earrings. They imitated the shape of the 17th-century ornaments, which consisted of four tiers. By the end of the 18th century, such earrings had three tiers already, and a massive brace clip. The upper tier consisted of an eight-petal flower. The top and bottom were framed with metal leaflets of various shapes. In the upper part they had a triangular shape with pointed tips, and at the bottom - a pair of convex pinnate lobes. The center of the flower itself was decorated with stones. Basically, these were red pebbles in the center and turquoise by the circle.

The middle tier resembled the shape of a bow of the dukach, which was also decorated with a red stone in the center and two turquoises on both sides. The lower tier consisted of pendants that had from seven to ten small coral beads and resembled a bunch of viburnum. The beads were fastened by the pins, with one end bent, so that the beads did not fell off. Sometimes they used a multifaceted red stone instead of corals. «Pereiaslav» earrings had been worn in many villages. Sometimes they had been customized, consisted of fewer elements. In such earrings, the lower part consisted of paired convex leaves, decorated with a turquoise stone on top. Often from these leaves were hanging coral beads in the form of a bunch. In some earrings, instead of coral beads, a red multifaceted pebble was hung, between which there were two lids. Such earrings, in some villages in Pereyaslav Region, were called «bow». In simplified variants, there was only circle with an eight-petal flower with a red glass stone framed by two-petal leaves. There are 8 storage unit such «Pereyaslav» earrings and their simplified copies in the collection.

Peculiar artistic features have earrings with pendants, the roots of which date back to ancient times. Similar jewelry, that reminiscent of moon shaped pendant are also known among jewelry of ancient masters. They were less spread in Pereiaslav region and had 
more complex structure. A shield that hung on a massive clip was often in the shape of one or two birds, with their backs turned to each other - (2 pieces) was hung to the massive ring. Not less popular were the arch earrings - (2 pieces) [1, p. 101].

Earrings from Poltava region -12 pieces of storage. Almost all of them are made of silver and remind of a circle with concave eight petals and a stone in the center. Decorated with carvings in the form of dashes and curves. The collection has 11 pieces of these «Kalachyk» (local name) earrings. One piece from the collection (odd), made in the form of a ball with an oblong leaf attached to it.

The dominant motifs in goldsmiths products of the Middle Dnieper region were the floral ornament, both in the product itself and in its ornamentation: serrated and wavy silhouette. The collection of earrings from Cherkasy region is represented by its leftbank land, that is, the former Zolotonoshi district of Poltava province.

Therefore, it is natural that some types of earrings have become widespread in both the present Poltava region and Cherkasy region. In the collection there are 4 «Kalachyk» (local name) pieces. Among this type, the most common were earrings in the form of an eight-petalled concave flower with a red stone. «Kalachyk» with convex six-petalled flowers has a slightly different shape. The «Knyshyk» massive earrings had a form of a large flower with petals convexed in two rows. The form, resembled «Knyshi» - festive pancakes.

The «moon» or «half-moon» earrings were very popular among Ukrainian women. Their shape resembled a steeply bent moon, hung by its horns. Metal beads were attached to the horns of these earrings. These earrings were made by most of the leftland goldsmiths, decorating them with rhinestones in the form of a floral ornament. The shape had an ancient origin associated with the cult of the moonlight.

In many villages they were called «flat»-( 4 pieces in collection). The local goldsmiths also often expressed their creativity in coin-made earrings. The collection holds two pairs of earrings made of «10 kopiiok» coin dated 1910 and the coin «25 pennia» dated 1917. The last one had pendants with wings. In the left-land Cherkasy region such earrings could be hung over with «butterflies», «wings», and «balls». Such earrings were called «Bovtyky». The «butterflies» had their wings raised up, and the «wings» had them downwards. The wings of the «wings» earrings were encountered much less often than the «butterfly» one. This was due to the fact that the fashion for «wings» existed in an earlier period, which had been gradually supplanted by the «butterfly» pendants. Only a few goldsmiths were known to make «wings» [2, p. 109].

The works of Ukrainian goldsmiths were distinguished by the construction of forms, shapes and decorative means, dynamics, plasticity, openness, variety and originality. Their jewelry can be recognized by the proportionality and expediency of all the components. One must emphasis multicolor of the products, their ornamentation and creative improvisation of the masters. In addition, Ukrainian goldsmiths have made an unlimited contribution to the treasury of world material culture. 


\section{References:}

1. Dunaina, I. (2016). Zhinochi prykrasy Perejaslavshhyny [Women's jewelry of Pereyaslav's land]. Nizhinska Starovina: Collection of Regional History and Memorial Science. Nizhyn-Kyiv: Center of Memorial Science of the National Academy of Sciences of Ukraine and Ukrainian Society of the Protection of Historic and Cultural Monuments, vol. 22(25), pp. 101-108.

2. Dunaina, I. (2018). Tvorchyj spadok siljsjkykh zolotariv u kolekciji ukrajinsjkykh narodnykh zhinochykh prykras z Cherkashhyny [Creative legacy of rural goldsmithes in the collection of Ukrainian folk women's jewelry from Cherkasy's region]. Nizhinska Starovina: Collection of Regional History and Memorial Science. Nizhyn-Kyiv: Center of Memorial Science of the National Academy of Sciences of Ukraine and Ukrainian Society of the Protection of Historic and Cultural Monuments, vol. 25(28), pp. 109-115.

\section{MUSEUM OF UKRAINIAN TOWEL NATIONAL HISTORICAL-ETHNOGRAPHIC RESERVE «PEREYASLAV»}

\section{Natalia Zaika ${ }^{1}$}

DOI: https://doi.org/10.30525/978-9934-588-11-2_25

Birth of a child and christenings, betrothal and weddings, seeing off and meeting dear guests - all these rituals were accompanied by a towel. Its ornaments contain ancient magical signs: images of the Tree of Life, Savers (Beregini), symbols of earth, water, celestial luminaries, which were further embodied and developed in a variety of customs and rituals. As a saver (oberig) the towel was transferred from family to family, from generation to generation. The Museum of Ukrainian Towel is located on the territory of the Museum of Folk Architecture and Mode of Life, in the northern part of Middle Dnieper area. The exposition, which was opened in 1995, is located in the building of the Three-Holy Church built in 1651 and moved from the village Pyshchiki of the Skvyra district of Kyiv region. Creating a permanent museum exhibit in a church room is connected with preserving the church as a monument of folk wood architecture and the need to demonstrate a unique collection of towels. In the 1960s and 1970s, when the Soviet authorities massively closed and destroyed churches, the question arose as to how to prevent this. In many cases, such premises were used to create museum facilities. The pereyaslav museums, headed by M. Sikorsky, also did this. The author of this article has published information about the temple [1], museum items on display [2;3;5], and about some aspects of museum formation [4]. The purpose of the study is to highlight the process of forming a collection of towels, the establishment and development of the Museum of Ukrainian Towel, as well as to promote the monument of architecture in which it is housed.

M. Sikorsky, director of the Pereyaslav National Historical and Ethnographic Reserve, said: «We have been collecting this good since 1952. If you knew how many villages our tireless women went: E. Nesterovskaya, I. Scotnikova,

\footnotetext{
${ }^{1}$ National Historical and Ethnographic Reserve «Pereiaslav», Ukraine
} 